\title{
The Functionality of Privacy Value in the Continuity of Family Unity
}

\author{
Dr. Handan Yalvaç Arıı* \\ İstanbul Sebahattin Zaim University \\ * E-mail of the corresponding author: handan.arici@izu.edu.tr
}

Conflicts of Interest and Source of Funding or financial support: None

\begin{abstract}
In this study, it is aimed to explain how the changes and transformations in the understanding of privacy affect the family structure, to reveal the functionality of the value of privacy in the continuity of family unity and to formulate suggestions for regaining this functionality Accordingly, the importance of privacy value, historical process of privacy starting from prehistoric times to the present, and the privacy understanding of today's family have been discussed. At the same time, the functionality of privacy is revealed in the continuity of family unity and suggestions are made for the determination of privacy principles and the implementation of these principles. It has been determined that the concept of privacy and accordingly family structure changed over time. It is understood that the state, non-governmental organizations and educators have important roles regarding family privacy.
\end{abstract}

Key Words: Religious Sciences, Family, Privacy, Value, Transformation

DOI: $10.7176 / \mathrm{JPCR} / 53-04$

Publication date: June $30^{\text {th }} 2021$

\section{Introduction}

Human existence is in search of eternity in a finite universe. The desire to stay tomorrow and leave a mark in the future often creates anxiety and this anxiety causes the individual to act with the idea of living everything in the world (Dökmen, 2000, p. 3-4). This thought of being permanent can limit the virtuous behavior of the individual or prevent the individual from acting principled. On the other hand, the primary behaviors for a person who discovers his own reality and existential purpose are the virtuous ones. Virtuous behaviors create private areas of the individual and draw boundaries against bodily desires and lust (Ibn Miskeveyh, 2013, pp.26-27). For individuals, living life in a virtuous way is proportional to knowing the limits of privacy. Privacy, which is regarded as one of the essential fundamental rights for human existence to live with dignity and honor, is a control-based right. This right implies that the individual sets limits between himself and his environment to protect himself against external interference in his private areas and manages these borders (Newell, Metoyer \& Moore, 2015, pp. 106-107). In other words, it is the limitation of the access of the individual to what he has materially and spiritually. The privacy boundaries or the activity of controlling the private area, prevent the individual from exceeding the confidentiality boundaries and compromising his fundamental rights in the personal and social space. Privacy, which expresses personal confidentiality, is not only an individual-based concept. There is also a private area belonging to the family institution made up of individuals. Just like the individuals, the family also has its own private area. Family privacy includes all of the private relationships and interactions between family members and also supports the protection of the family by placing limits on its material and spiritual interactions with its environment. As family privacy protects the whole family, it also includes family members within the protection area.

Privacy determines the relationship dynamics between family members, the unique privacy and boundaries of the family, and also creates a safe living area for the family inside and outside the family. In this study, first of all, the value of privacy has been defined, the historical process of family privacy from prehistoric times to the present, and the changes and transformations of the meanings attributed to privacy in this process has been evaluated. It is aimed to explain how the changes and transformations in the understanding of privacy affect the family structure, to reveal the functionality of the value of privacy in the continuity of family unity and to formulate suggestions for regaining this functionality. 


\section{Method}

This study, which is an example of qualitative research, was conducted according to the "document analysis technique". Qualitative research is a type of research in which qualitative data collection methods such as observation, interview and document analysis are used and a process is followed to reveal the events in a realistic and holistic manner in the natural environment. In other words, qualitative research is an approach that prioritizes researching and understanding social phenomena within the environment they are connected to, with an understanding based on theorizing (Y1lirım, 1999, pp.3). Document analysis is an indispensable data collection technique for almost any research. Researchers spend a significant part of their research process on reviewing and evaluating previous research. The most important feature of document analysis is that communication between the researcher and the document is mandatory. The more the deviation between what the document wants to tell and what the researcher understands, the more successful the communication becomes (Karasar, 2007: pp. 184). Document analysis, which is used in most of the qualitative researches, includes the analysis of written materials containing information about the phenomenon or facts to be investigated (Madge, 1965, pp.75). This technique enables the analysis of documents produced in a specific period about a research problem or documents produced by more than one source and at different intervals on the subject (Yıldırım \& Şimşek, 2018 pp.12).

Document analysis involves skimming (superficial examination), reading (thorough examination), and interpretation. This iterative process combines elements of content analysis and thematic analysis. In the study, content analysis technique was used to evaluate the obtained data (documents). Content analysis is the process of organising information into categories related to the central questions of the research (Bowen,2009, pp.3). The basic process in content analysis is to gather similar data within the framework of certain concepts and themes and to organize and interpret them in a way that the reader can understand (Y1ldırım \& Şimşek, 2018, pp.18). Falkingham and Reeves (1998) also stated that content analysis is a new method used for the evaluation of publications. Accordingly, the issue of family privacy in the transition from traditional family to modern family has been divided into categories and subcategories. The limits of family privacy have been drawn in line with the opinions of the experts and the problems caused by the change and transformation identified have been evaluated in detail. As a result of the study, it has been seen that both in family and out-of-family attitudes there are serious changes in the transition from the traditional family to the modern family. It has been understood that these changes negatively affect the unity of the family, cause family members to become alienated from each other and have an impact on divorce. Depending on the results obtained, suggestions have beeb offered to functionalize the value of privacy, which is necessary for a healthy family; to raise awareness of families about media and technology literacy to protect family privacy; to create family privacy sensitivity on social media; to spend quality time in family communication and to respect private spaces and to raise the awareness of children on parental rights, compassion and love.

\section{What is Privacy?}

Privacy, which has an important role in the ontological continuity of human existence, is considered as the subject of many disciplines such as psychology, sociology, theology, law and anthropology. The word "mahremiyet", which has been translated from Arabic to Turkish, means confidentiality in dictionaries (Akalın, 2005, p.1328), while the root of the word, mahrem, means a person who is forbidden by religious, who is not considered correct whose marriage is not permissible in terms of shariah (Doğan, 1996, p.729). The word "mahremiyet" is etymologically derived from the root "h-r-m", it means that something is forbidden, something is top secret and something is revered, honored, respected (Ibn Manzur, 1997, p.136), and it is defined as something that is forbidden by reason or shariah or by someone who is being obeyed (Al-Isfahani, 2002, p. 229). Also, the root of the word includes the meanings of immunity and deprivation (Okuyan, 2019, p.191).

For example, making Kaaba or the city of Mecca forbidden states a ban in terms of immunity and holiness (alMaida, 5/97). Therefore, the concept of privacy shows the limits set due to immunity and showing respect. The concept of privacy, which is used in the meaning of private area expressed with the word "privacy" in English, derives from the Latin verb "privo, privare" and means to set aside, separate, deprive. The word "piravatus", derives from the verb privo and used as an adjective verb and noun, is used in singular, individual, personal, privileged meanings (Ernout \& Meillet, 2001, p. 536). In the modern period, according to the paradigm based on individualism, privacy is considered as the right to be alone (Warren \& Brandeis, 1890, p.193).

In psychology dictionaries, the concept of privacy defined as respecting the individual and does not make sharing about him; and the area that belongs to each individual (Reber, 1985, p.574), or the individual's access to 
others for a certain level of physical or psychological isolation, the selective control activity to protect himself or to reserve others (Trepte \& Masur, 2017, p.1). While some of the social scientists define the concept of privacy as withdrawal, non-interaction, most of them define it as the control of the accessibility or inaccessibility of private life to others and the freedom of choice or selective control over the individual's effort to reach himself or his group (Altman, 1976, p. 7-8). Studies on the biology of privacy reveal that privacy is not a behavior specific to human existence. Anthropological studies show that animals react to privacy, such as moving away from the herd, being alone, retreating during nesting and breeding, and attacking to protect their own species or the boundaries of their herd (Westin, 1968, p.9-10).

Privacy is the ability of the individual to control himself, draw boundaries of his private area, and free his existence in the public area from all authorities. The individual gains individuality when he draws boundaries, limits and completely separates himself. For example, veiling is a boundary; it is the setting of a boundary for the individual to separate herself from the environment (Fazlığlu, 2020, p.63). Privacy is the freest area of the individual. It refers not to having something to hide, but to the areas where the individual will not even need to consider whether there is something to hide (Lokke, 2020, p.22). Because these areas are independent of the social spaces in which the individual is responsible for his behavior. Freedom is limited in the part of behaviors that concerns others and reflects on the social. The right of absolute freedom for the individual is the area of privacy and this area supports the individual's access to real freedom. Real freedom is the ability of an individual to control his life as a whole, to plan his life and to act with the knowledge that he will be responsible for the consequences of what he has done. In other words, privacy teaches the individual not to be captive to his desires and wishes, which is worse and dangerous than slavery and be away from false freedom that makes him trapped in temporary desires (Guzman, 2005, p.25-26) (Neiman, 2017, p.57).

Ontologically, freedom for human existence consists of three elements. The first is the freedom of conscience, thought and emotion; the second is designing one's life following his personality provided that he suffers the consequences on the condition that they bear the consequences, and the third is the freedom to unite with others for any purpose without harming others (Mill, 2011, p.15-16). Therefore, privacy is the possibility of an individual to be independent of all authorities, to be himself and to realize himself. While privacy, which gives the individual the right to absolute freedom, is classified in seven parts in western thought as an individual, behavioral and action, communication, data and image, thoughts and emotions, area and area, and togetherness with social groups (Finn, Wright, \& Friedewald, 2013, p. 4) is generally handled from three perspectives as spatial, individual and information.

a. Spatial Privacy: It refers to the effort of the individual to protect the places he is in, such as home, workplace or public area, or the physical areas that have a close relationship with him even though he is not present (Fischer-Hübner, 2001, p.6). Spatial privacy reveals an important distinction between inside and outside of the dwelling, limiting the action of entering the dwelling from outside even if the door of the dwelling is not durable and the lock is insufficient. In this way, it protects the privacy of the individual and the people who are with the individual (Vincent, 2017, p.15).

b. Individual Privacy: It is seen as the effort of the individual to protect all kinds of fundamental rights, including biological, psychological, social, legal and political (Fischer-Hübner, 2001, p. 6). Individual privacy is accepted as the right of the individual to exercise control over his own private area (Lokke, 2020, p.19) and to protect his physical and psychological activities (Finn, Wright, \& Friedewald, 2013, p.4). In other words, it is understood that the activities aimed to protect the existence and existential continuity of the individual are among the personal fundamental rights.

c. Information Privacy: It refers to the requirement that the situations related to the collection, storage and disclosure of personal data should be under the control of the individual (Fischer-Hübner, 2001, p. 6). The fact that the data belonging to the individual is not used automatically by other individuals and organizations without his consent reveals the obligation of only the individual to have control over these data and their use. (Finn, Wright, \& Friedewald, 2013, p.5). As a result, each individual has three basic rights related to privacy: spatial, individual and information.

The concept of privacy is evaluated from four perspectives: metaphysics, psychology, morality and politics in Islamic thought. Each evaluation topic is handled in a concept axis. First, the concept of privacy is seen as a metaphysical problem centered on existence and present. Secondly, it is discussed on a psychological basis in the axis of self-concept. Third, it is negotiated in terms of the virtue-centered problem of moral and morality. Finally, it is studied as a political problem in the axis of the concept of justice, which has many sub-dynamics such as freedom and equality. Each of these four evaluation areas has sub-problems within itself (Türker, 2019, 
p.92). Therefore, the concept of privacy is seen and discussed as one of the primary issues of ontological, psychological, moral and political philosophy in İslamic thought.

It is known that the concept of privacy varies from culture to culture, from nation to nation, and sometimes from individual to individual (Westin, 1968, p. 29). Especially, this concept has different meanings in the east and west perspective. While the concept of privacy is built on immunity in western culture, in eastern culture it is built on invisibility. In western culture, privacy states that the individual is inviolable in the public area and his fundamental rights are guaranteed. In eastern culture, it means being intimate; and being intimate means being hidden from someone else's glance and being closed to visibility. Therefore, privacy in western thought and culture means that the private area of the individual is secured from all kinds of intervention, and in the eastern culture, it means that the private area of the individual is closed to the outside (Yavuz, 2012, p.18). In other words, privacy in western culture is the creation of borders from the outside to the inside and in the eastern culture from the inside to the outside. While the duty of protecting the privacy of the individual in western thought is the responsibility of the state, in the eastern culture, especially in Islam, this duty is primarily attributed to the individual. Because it is the individual who will determine the boundaries of privacy and prevent interference with those borders.

\subsection{Understanding of Privacy in the Western History}

It is thought that the concept of privacy takes place on the human stage with the creation of human existence. In the Torah and the Bible, the creation story of human beings takes place and the trace of privacy is seen in this story. In the Torah, it is stated in the creation story of Adam and his wife that although they were forbidden to eat the fruit of a tree, they ate from that fruit in search of eternity and that Adam and his wife remained naked, covered themselves with fig leaves, and escaped from God and hid among the trees (Old Testament, Genesis, 3 : 1- 10). This story in the Torah shows that the need for privacy of human existence emerged with genesis. As of the prehistoric period, the concept of privacy has started to take place in the historical process. It is known that even in primitive and nudist communities there is a feeling of embarrassment, biological needs such as the need for toilet and flatulence are not made openly, on the other hand, when such needs are clearly met, there is such shame as an attempt to commit suicide. (Duerr, 1999, p.191, 196-197). Also, it is seen that all primitive societies establish privacy boundaries according to their social structures; in these societies, full nudity is not accepted or can only be accepted among a few tribes, private boundaries of the family are lived in the privacy of the home, and family privacy is not allowed outside (Westin, 1968, p. 14-15).

In B.C 1972, not breaking into the house of Hammurabi, who was the sovereign of Babylon lands; even taking protective measures to prevent unauthorized entry into the house is considered as the first institutional activity in the history of privacy (Solove, 2011, p. 4). In the Roman law applied from B.C 753, which is accepted as the founding date of the city of Rome, until 565 A.D., the year of the death of the Eastern Roman Emperor Justinian in Rome and the countries where Rome dominated (Güneş Ceylan, 2004, p. 4), surveillance and protection against surveillance laws are activities aimed at protecting privacy (Solove, 2011, p. 4). In ancient times, taking care and obeying was deemed important in Roman politics and symbols of authority were effective in shaping life and architecture. In ancient Greece, since showing and displaying was a priority, openness and nudity showed itself in art and architecture. Especially with sculpting, the human face and body were revealed in all details (Sennett, 2002, p. 78-79). It is understood that the perception of privacy in antiquity is mostly centered on protecting the life of the individual and the exposure of the bodies is not considered within the scope of privacy.

The Medieval Age, between A.D 375 and 1300, represents a theocratic period composed of feudal units. It is known that a theologically centered society was built in the west and Christianity became an institutionalized religion (Ağaoğullar \& Köker, 2004, p. 92-93). According to the medieval perspective, human has to behave according to God's commands, not reason, since he fell from sacred to darkness because of his mind. Otherwise, one has to be a slave, not free. The only way to get rid of this position of slavery is to obey theocratic rules (Akgün, 2013, p. 125). For this reason, there are no individual freedom areas such as eating, drinking and dressing as the medieval people wanted. Individual freedom is not included among the freedoms, the individual has to depend on his role in the social order. Individual and social vital activities are carried out within certain rules. The areas determined by theocratic rules are evaluated within the scope of freedom (Fromm, 1995, p.48). Therefore, in the Middle Ages, it is understood that the principles of privacy were shaped according to Christian thought and that privacy was experienced in a very narrow area.

With the increase in trade in the 11th and 12th centuries, it is seen that the interactions between societies increased, new ideas emerged, and social reconstruction movements began with the Renaissance, also known as the Age of Enlightenment, which means rebirth against the scholastic order from the middle of the 14th century. 
(Çoşkun, 2003, p.48). In the 14th century, in case of trespassing, homeowners were given the right to sue for the invasion of their premises. It was thought that there should be an important distinction between the interior and exterior of the dwelling as a settlement, even if the door of the house is unstable or unlocked, or if there are common walls, permission was required for the act of entering the interior, thus privacy was protected by laws (Vincent, 2017, p.15). On July 13, 1341 in London, John Lutet's wife Isabel's neighbor John de Thorp's application to the court because the walls of his house were not high enough and he was observing his private life and violating the privacy, reveals the sensitivity to protect individual privacy. In the 14th century, although privacy concerns arose, privacy was not a guaranteed right. It was considered a hard-to-find and controversial commodity (Vincent, 2017, pp.11-12, 17).

In the 14th century, houses were single-roomed, with chests or closets where only personal clothes and valuable items are stored. Chatting, sleeping, cooking, eating and even the toilets were in the same room in the houses. Only the upper classes socially had the opportunity to experience a sense of privacy. In the 15 th century, breaking into houses and stealing began to be considered among the serious crimes. (Vincent, 2017, pp.22-23). Within 200 years after the 15th century, house designs have changed and comfort areas have emerged in homes. The diary keeping and the spread of the letter in the early 16th century created new limits on private life (Vincent, 2017, p. 36-38). In the 17th century, privacy was accepted as a necessity of humanity, and any action to protect privacy became permissible (Niedzviecki, Dikizleme Günlüğü, 2010, p.237). Advances in urbanization and mass communication by the 18 th century drew new limits on privacy. Private areas were created where individuals could retreat. Comfort in homes has increased and spatial privacy has become more pronounced. Such that the use of glass and curtains has become widespread to completely separate the house from the outside (Vincent, 2017, p.51-53).

The 19th century was the golden age of privacy; houses began to be regarded as the center of privacy and the family as the place of God in the world. Shared privacy as husband and wife, parents, and children protected the social balance. The phrase "sacred veil" denoting privacy emphasized the moral power of privacy. In the 19th century, with an industrial renovation, the kitchen and dining room; living room and salon were separated from each other in the houses; study rooms and even bedrooms for children were built in new-style houses; thus individual privacy areas expanded. In the streets of many cities around the world, gas lamps started to be used and public transportation systems started to develop (Vincent, 2017, p.91, 96-97). In this century, the electronic communication revolution was made with the use of the telegraph (1830) and the telephone (1876). With the pornography market in the late 19th century, privacy began to be commodified. The publications made aroused curiosity and increased the demand for gossip. So much so that journalism was tried to be separated from pornography by enacting the "Obscene Publications Act". On the other hand, with pornography, the first steps to limit privacy limits were taken (Vincent, 2017, pp.114-122).

In the 20th century, new privacy areas were being created, the privacy of the individual was prioritized and family privacy was deprived (Yeşil Çelik, 2020, p.23). In this century, a definition of privacy was made. In the Universal Declaration of Human Rights in 1948, it was stated that no one could arbitrarily interfere with their private life, and in Article 8 of the European Convention on Human Rights published later, each individual has the right to respect for his private and family life, home and correspondence (Seipp, 1983, p. 350-1). In the second half of the 20th century, demands for leisure and entertainment increased, privacy began to be seen as pleasure and pleasure, long-lasting marriages came to an end, and illegitimate behaviors were supported. The boundaries of privacy, which were seen as pleasure and delight, were subjected to a great change (Vincent, 2017, pp.152, 156-157).

As a result, when the understanding of privacy is evaluated from Antiquity to the present, it is seen that privacy has been attributed to different meanings in the historical process and the limits of privacy have changed. It is understood that this change and transformation affect the individual and society negatively.

\subsection{Understanding of Privacy in the Islamic History}

Privacy is defined as " right of privacy " in human law; in modern law, it refers to protection from the intervention of foreigners and is seen as a "right of personality"; and in Islamic law, it is defined as "the living area that is generally protected from others by moral and legal sanctions whose scope and boundaries are determined by the Shari. (Pekdemir , 2016, p.130). In the pre-Islamic Arab society, witnessing the intimate states of others and entering others' homes without permission were not within the confidentiality limits (Y1ld1z, 2020, p.38). On the other hand, with the religion of Islam, the boundaries of individual and family, area and information privacy are clearly laid out. The Qur'an requires permission to enter the houses (Bakara, 2/189), pay attention to the privacy of the houses (Nur, 24/27), not to investigate the shame of people (Hucurat, 49/12), and 
protect family secrets (Tahrim, 66 / 3-4). Therefore, in Islam, it is understood that the boundaries of privacy are drawn as individual, spatial, familial and knowledge, and the individual should live by paying attention to these limits.

The orders and recommendations of the Quran regarding privacy contain invariance from the first addressees to the last ones. The binding nature of the Quran and tradition has made the understanding of privacy in Islamic societies an important position. For example, in the Ottoman Empire, the intimate boundaries also appear in the neighborhood boundaries. So that the residents of the neighborhood are seen as surety for each other. The privacy of the area was reflected in the architecture in great detail, shops were not allowed to be opened opposite the street doors, and thresholds were placed when entering the houses to clarify the inside and outside boundaries of the house. Hence, passages between courtyards in palaces were provided by a few gates with certain distances (Tunç Yaşar, 2019, pp.53-56). The change and transformation in the world in the 16th and 20th centuries affected Islamic geography as well, and privacy measures began to change in Islamic societies. The privacy hierarchy outside the home boundaries had changed, and privacy at the neighborhood boundaries had been drawn into the family. As of the 19th century, men's greetings became places used by men and women together, and the harems, which are private areas for women and children, became used by the family. In the 19th century, family privacy was a free area where individuals connected to each other with special feelings lived and no one could interfere (Tunç Yaşar, 2019, p.57-64). With the advancement of technology in the 20th century, the world has become a global village, as a result of this globalization, individuals become aware of each other very quickly and affect each other. This interaction causes people built by different cultures and different beliefs to create common lifestyles (Balay, 2004, p. 62-63).

\subsection{Today’s Understanding of Privacy}

With the modernism that made its mark in the 20th century, it is seen that many social structures such as family, social relations, religion, customs, politics and art have taken place by showing the influence of philosophical ideas such as secularization, liberalism, capitalism, which are components of modernity (Touraine, 2010, p.25. ). It is understood that modernization emerged as an aggiornamento movement and that this movement was built on the understanding of distancing from the past and the tradition. "Modern man" who has the concept of modernization means an individual who thinks like a westerner and lives like a westerner (Kızılçelik, 1996, p. 9). It is thought that the beginning of the end for privacy began in the 1960 s with the influence of a postmodern philosophy (Vincent, 2017, p.178). With postmodernism, there is no value left to be experienced as reality or truth, and the value has become an object produced in the moment by being detached from its worth. The lack of a stable value causes the actions to become transparent by enlarging the ambiguous areas and the freedom to become unlimited and absolute. At the same time, the universality value of modernism is displaced and universal values and universal morality are replaced by personal morality (Çăgan, 2019, p.11-19, 20).

According to the postmodern understanding in which the values are diminished; daily life, pleasures, desires and wishes should have priority for the individual. This point of view creates a consumption culture. Thus, by increasing the functionality of capitalism, consumption areas expand and unnecessary products are made into need. So that consumption culture creates the consumption society and each individual is seen as a consumer (Baudrillard, 2008, p. 98). The understanding of privacy undergoes great changes and transformations with the imposition of today's philosophies such as modernism, postmodernism and capitalism, as well as the spread of the internet and the increase in the use of social media (Aydın Avşar, 2019, p.53). With the use of the internet, communication and interactions are done through the windows of the computer. The most effective of these windows are the social media platforms. In these platforms, there are profiles in which individuals introduce and express themselves. The desire to be visible on these platforms causes the individual to share even the most private areas. The request for privacy that is visible creates the paradox of privacy. Even individuals who want to protect the boundaries of privacy find ways to be visible (Sayar \& Yalaz, 2019, p.189). Thus, the distinction between private and public areas disappears and private areas become a part of the public area (Arık, 2018, p.14). As a result, there is a digital panopticon era.

The understanding of "panopticon", which means "to observe the whole" introduced at the end of the 18th century, offers a perspective of unseen surveillance that changes the measures of privacy. This understanding put forward by Jeremy Bentham is the philosophy of keeping the large masses of the period under control (Özdel, 2012, p.23). Panopticon is planned as a prison model to be used for the surveillance of criminals. In this model, a circular building and cells facing the courtyard in it are designed in order to create centrality, and at the same 
time, a watchtower is built in the middle of the building and all power is given to the watcher (Bentham, 1995, p.35-37). There is now a digital panopticon, even multi-directional surveillance and syneptic, where the majority watches the minority (Demir, 2017, p.59). The privacy boundaries of a society under constant surveillance are disappearing. As Mark Zuckerberg, the founder of Facebook, the first of social networks, said, the era of personal privacy is coming to an end (Çağan, 2019, p. 15).

Panoptic privacy limits private areas and causes an external intervention, as well as individuals' own actions carry their private area to the public, making privacy obvious. Therefore, there are external and internal threats to privacy. It is generally considered that there are three sources of privacy threat: selirevelation, curiosity, and surveillance. Selirevelation from sources of threat to privacy is the provision of verbal or visual information to the close or distant environment of the individual about his private life. Although the individual himself made statements about his or her private life, these disclosures violate privacy. Curiosity, regarded as the second source of threat, is an inherent tendency for human existence. Because of this tendency, the individual wants to be aware of what is happening around him. Curiosity, which provides many benefits to the individual in terms of obtaining information, can direct the individual to research confidentiality in social life and inform the individual about the information that should not be known. The desire of an individual to be aware of the life around him means an intervention in the privacy of those around him. The last source of threat to privacy is surveillance. Surveillance is an action performed as social control. It is the control of individuals by observing each other within the social hierarchy. It is seen as an obligation of the social order for the teacher to monitor his students, parents' children, and the citizens of the state. However, when this surveillance goes out of control, privacy is violated (Westin, 1968, pp. 52-62). As a result, actions that violate the limits of privacy such as selirevelation, surveillance and surveillance can easily be carried out with today's philosophies and developing technology. Thus, the limits of privacy are blurred.

\subsection{The Effects of Today's Understanding of Privacy on Family}

The family, which is the primary type of social relations, in which lived together in, which is the most sincere and warm environment of the individual and accepts the individual with his existential value (Ergil, 1984, p. 1516) is seen as the most functional element of social organization and institutionalization (Kır, 2011. , p. 381). The family is a personal and collective living area in which the individual feels most comfortable, think that he is understood, can protect his privacy, he is cared for and care for those who care about him, and where he is the right to be alone (Zeldin, 1998, p.384). It is seen that the meanings attributed to the family (Canatan \& Yildırım, 2011, p.83, 89), which is accepted as the most powerful dynamic of the social structure for social control and social design; and transfers social values, social rules, beliefs and culture to the individual in the continuity of the social order, has changed and transformed over time. . Understanding of modernism and postmodernism affect the family structure, male-female relationships and roles change. Especially, it is observed that the family structure in eastern societies is affected more by modernity compared to the family structure in western societies, and there are more conflicts and polarizations between family members. Because the traditional family structure in western societies is almost in a state of extinction (Karagülle, 2015, p.43).

In the modern family structure, a few generations do not live together as in the traditional family, even the family turns into a nuclear structure as much as possible. Since the members of the modern family work outside the home, public institutions take care of the children, patients and elderly people of the family; and many activities such as education, socializing, entertainment, recreation are held outside the home or on virtual media. While almost every frame of life is lived together in the traditional family, vital activities are experienced individually in the modern family. Thus, warm family environments cool down and every individual in the family prefers to live their own life in isolation from their family (Subaş1, 2007, p. 108-112). As a result of these preferences, the family in primary relationships dissolves and takes the form of a secondary relationship, which is a formal and partial relationship. The family, which transforms from the large to the nucleus with the preferences of lonely life, turns into new family structures such as single-parent families, temporarily extended families, contract marriages, childless couples, family clusters. In the family built by modernism, it is observed that marriage has moved away from institutionalism and being child-centered, especially as of 1970, childless families have increased and even "child-free" families gain prestige in the 21 st century (Alvin Toffler, 1981, p. 288-291).

With the separation of the family from institutionalism and the purification of the child, sexuality also gains a new dimension, and it is accepted as giving up pleasure and is constantly provoked. With the development of reproductive technologies, sexuality is separated from a spiritual thought such as the need for reproduction and 
turned into a plastic one. So that sexuality is completely liberated because pregnancy can be produced artificially instead of being artificially prevented. This plastic deprives the institutional coexistence that is responsible for sexuality, and at the same time, sexuality, which is transformed into a decentralized, idle state, is carried from the private space to the public and harms family privacy. (Giddens, 1994, pp. 31, 7-8). It is understood that this understanding, which only and only prioritizes pleasure and makes sexuality a goal, even saying parents, as set forth in the disoptic novel "Brave New World", can be seen as immoral and cause the family to collapse completely (Huxley, 2013, p. 49, 160). Particularly in newspapers, magazines, and the internet, the details of sexual relations are given in detail to satisfy lustful tastes. Thus, commodified sexuality, which is widely publicized, is forced into the domain of homes (Vincent, 2017, p.178). One of the important factors that make plastic sexuality peak is the use of bodies as objects of pleasure. Metalized bodies take the shapes determined by modern culture (Barborosoğlu, 2013, p.15).

At the same time, sacredness is attributed to the metalized bodies; the aging of the body, the ugliness of the body, and the presence of a physical defect are never accepted and it is thought that these incidental situations should be eliminated immediately. The perfect and admired types of men and women imposed by the media become the beauty criteria individuals want to achieve (Bruckner, 2012, p.11). In order to reach these criteria, many surgical interventions such as facelift, liposuction, nose aesthetics are performed. The exposed bodies are used to be attractive, to create desire, to provoke and to keep sexuality on the agenda. Unfortunately, in the consumer society, the body is coded as a fetish value, seen as symbolic capital and a kind of economic investment. Sexuality, whose boundaries expand as it becomes commodified, which is presented on every occasion in the public space, which provokes desires; means getting more pleasure and the expectations of spouses to satisfy each other change (Köse, 2011, p.78). At the same time, the differences that do not comply with the beauty criteria set by the media cause the comparison between spouses and the tendency to see the differences as defects. Unhappily, sexual fantasies advertised with constantly flowing visuals turn into production areas. Thus, spouses tend to seek satisfaction not with each other but in different relationships. This orientation destroys the family institution.

With the individualization of collective life experiences, family ties are severed, and this disconnection in the family also weakens intimate and trusting relationships such as kinship and neighborhood (Aktaş, 1995, p. 45). Thus, social networks where individuals who live disconnected from society can define themselves on the social platform are becoming widespread. Thanks to these networks, time and area limitations are eliminated and social relations continue in a virtual manner (Aydın Avşar, 2019, p.54). Thanks to virtual social relationships, everyone is aware of each other and individuals try to model the lifestyles they see, whether they are following their beliefs, principles, or culture. The perspective of "being like" in an image-centered lifestyle is reflected in every aspect of life (Barbarosoğlu, 2017, p. 16). Especially the understanding of being like someone and being satisfied by consuming brings consumption to a peak. A life understanding based on continuous buying and consuming makes the individual and society a consumer. The desire to be satisfied as they consume shows everything material and spiritual as a means of consumption. With the spread of consumption in all areas of society, societies turn into a consumption society. Consumption society not only forces individuals to buy new clothes and new items, but also makes their relationships exhausted (Zeldin, 1998, p. 114).

The "throw-away" perspective of capitalism not only makes things worthless, it also carries human relations into an artificial form. It is used as if all objects and relations were to be consumed (Toffler, 1974, pp. 54-75). At the same time, every object, important or insignificant, is turned into a need, luxuries are seen as a need. This continuing passion for receiving drives the individual into addiction. The pleasure economy, imposed on the consumer society, creates new addictions such as constantly shopping, constantly surfing on social media, and being addicted to sex. Passionate addictions enough to enjoy first, then show continuity and then lose self occur (Giddens, 1994, p. 26, 70-71). The consumption culture turns families and society into standard masses; the masses are quickly aware of each other's actions through communication technologies and are influenced by each other's actions. The main elements of the social, which has become a mass, are being replaced by simulations. Facts are consumed, simulations are perceived as real, and a single understanding prevails (Baudrillard, 2003, p. 24, 14). As described in the dystopian novel "1984", it is understood that individuals are asked to have the same thoughts on every subject, and a single type of person is tried to be produced (Orwell, 2019, p.223). It is seen that even the lifestyles of believers and non-believers start to become the same, and believers do not act in accordance with religious references (Critchley, 2013, p.28). 
As a result of a mentality that has become massive and has made consumption a goal, a Fordist understanding that provokes consumption, that is a production model in which industrial production is transformed into mass production to a great extent and which accelerates standardization (Sakl1, 2013, p. 109) is formed; and as a result, a stagnation and collective consciousness occur in production and consumption. So much so that this collective consciousness causes the desire to to travel as everyone travels, have fun as everyone enjoys, and live as everyone lives. (Arrk, 2010, p.53). For example, even if the concepts determined for birthdays, henna nights, new year celebrations, weddings, baby mawlutes are not suitable for the family's budget, they are tried to be made in a way, and as a result, economic problems occur in the family and communication problems occur between family members. Despite all the negativities, every effort is made to realize this kind of ostentatious organization. In the virtual media, the image of a family that is always smiling, wandering, having fun, is given, and the family life is advertised immeasurably with selfies, location notifications and videos of the special family life. Thus, persuasion efforts towards images about the family convince the family members rather than the environment, and the family in the imaginations of the family members differ from the family they live in (Sayar \& Yalaz, 2019, p.70). Consequently, consumption culture commodifies privacy, and the actions taken to reach every item shown as a need and to resemble the masses damage the intimate areas of the family.

Media and social media play a major role in transforming family privacy. The lifestyles of people in movies, TV series or shows broadcast on television are presented interestingly. At the same time, the lives of individuals who have a media life style are followed through social media. It is observed that individuals aim to live in a comfortable and happy lifestyle just like famous people or people who are widely followed on social media. This target makes all kinds of behavior permissible in order to resemble those who are phenomena. Even though some people cannot be a phenomenon, they go on the path of satisfaction by making short videos of their lives similar to phenomena (Niedzviecki, 2011, p.139). Famous and luxurious lives, which are constantly presented in virtual environments, affect the thoughts and feelings of the individual. Seeing or watching behaviors that violate privacy constantly, such as good-hearted people prefer to commit bad deeds when exposed to bad conditions (Neiman, 2016, p. 406), causes the individual to prefer disclosure rather than protecting individual and family privacy. The individual who aims at the lifestyles seen in the virtual world becomes alienated from both himself and his family as he acts in line with this goal. The behaviors of characters in movies or TV series or phenomena in social media are idealized and expectations in family life increase and these expectations often do not match the person's reality.

Privacy measures shaped by today's presentations of philosophies such as capitalism, comfortism, secularism, modernism; digital developments and social media become limitless and even commodify. With the disclosure of secrets and violation of privacy, the phenomenon of alienation among family members occurs. In the modern world, as the boundaries between the public and private areas blend, the private area is destroyed, privacy violations become commonplace and public. As a result, in addition to being displaced in the world, individuals are deprived of the warmth of a home, where they feel protected against the outside world, experience all their special feelings, have narrow boundaries and also provide the most free opportunities (Arendt, 2018, p.105). This deprivation harms the individual and family. It is known that there is nothing that can make up for a lost life or family life properly (Zeldin, 1998, p. 456). Protecting the family is possible by preserving the privacy of the family and the limits of privacy. In order to protect the individual and family, first of all, privacy areas must be protected. Otherwise, it is thought that thoughts and actions based on the perspectives of media and social media actors will devalue the family institution, thus the most important dynamic of the society will become dysfunctional, and suggestions are made about what to do.

In order to protect the privacy of the individual and the family, four important solution proposals are provided: providing children with early and continuous education, informing them what to do with the data collected on their rights, creating alternating interest categories, and making basic arrangements by the state that allow good actors to develop. The first of these is to educate children at an early age to create the basis for the correct use of technology. Technology, which is the language of the 21 st century, is an indispensable part of today. In order to understand what marketers, media and technology companies do and to communicate with experts who can evaluate their claims, the alphabet of digital technologies must be taught. The second solution proposal is that commercial and social media companies are known to collect data about their customers. It is anticipated that by providing information to customers regarding what and for what purpose these data are collected, individuals may prevent the disclosure of personal information they do not want (Turow, 2011, p. 197-198). 
The third of the suggestions presented to prevent the violation of privacy is the establishment of relevance categories. It is thought that sending ads or videos suitable for specified categories such as children, teenagers and adults by advertising companies or companies instead of sending random advertisements to individuals will help children and young people not to be exposed to negative content and to take actions that may be wrong. Finally, making basic regulations by the state that allows good actors to develop is an opportunity for industry actors to be productive in the digital environment. However, some companies are known to attack data if not for competition. For this reason, data companies should be prohibited from using what individuals say in social media discussions or chat rooms without permission for marketing purposes. Otherwise, this data turns into a commercial commodity for some companies. The purpose of these recommendations is not only to set certain rules, but to encourage people to examine, question, understand and criticize the twenty-first-century advertising and media systems and rules and to raise their awareness (Turow, 2011, p.199-200). As a result, the recommendations regarding the protection of privacy limits, especially those in the digital dimension, can be considered as a protective measure against digital dangers against individual and family privacy.

As a result, privacy is a private area where the individual and family define their own boundaries and live freely. For the continuity of the private areas of the individual and the family, privacy measures must be protected. Failure to maintain the measures of privacy means being condemned to the standards drawn by others. Behaving according to the measures of others means that a person sees his own measures as inadequate (Müftüoğlu, 2019, p.42). Today, privacy measures change and transform with the influence of today's philosophies and virtual media. This change and transformation differentiates the lifestyles of family members and dissolves the intimate area of the family. When the sociological data and observations on this subject are evaluated, it is revealed that privacy is an important factor for families to live a happy and decent life in the past and today. It is thought to be a mechanism that builds factors that keep the family alive, such as developing the ego of the intimacy relationship; long-term desire for satisfaction; freedom of choice; balance and reciprocity in relationship; compromise; sharing wishes and feelings, honesty; confidence; spouses accepting each other's individuality and caring for each other; non-passionate love; healthy interests of spouses for each other's well-being and development; solving problems together; the formation of a comfort satisfaction cycle and solving problems before they reflect on society. (Giddens, 1994, p.26) It is observed that the families who are conscious, consistent and responsible are happy and peaceful; and there are disintegration in the families, in which privacy is violated, family members are alienated from each other and a process that goes up to the breakup of the family is experienced. (Kahraman, 2019, p.80).

\section{Results and Recommendations}

Privacy, which expresses the ability of the individual to control himself and draw boundaries in his private space, is an important value for individual, family and community life. Privacy is important to protect the material and spiritual life of the individual, to ensure the continuity of the family and the continuity of the society. The continuity of the family is important for the protection of the individual's material and spiritual life and for the continuity of the society. Protecting the family is possible by preserving the privacy of the family and privacy limits. Otherwise, thoughts and actions based on the perspectives of today's dominant powers, media and social media actors will devalue the institution of the family, thus the most important dynamic of society will become dysfunctional.

In this study, it was concluded that many activities related to family privacy can be done. According to the findings of the study, it is understood that the state, non-governmental organizations and educators have important roles regarding family privacy. First of all, academic and field studies should be carried out on individual privacy, family privacy, area and information privacy aimed at disclosing the individual's selfdisclosure and not violating the privacy of the people around his by revealing the principles of privacy in discourse and actions; and support should be created to create privacy awareness individually and socially.

It is known that in order to create a social awareness and make them gain a habit, children should be given practical training on that subject. In order to create privacy awareness, children should be given practical activities related to privacy and private space in the home environment, kindergarten and primary schools at an early age. For example, it can be emphasized that while the child is dressing or taking a bath at home, his body is unique and should not be shown to anyone. Likewise, in kindergartens and primary schools, children should be asked to pay attention to privacy in cases such as sink use and changing clothes. At the same time, it is thought that increasing the activities such as games, drama, learning by experience and performing these activities systematically and regularly will support privacy education in kindergartens, primary and secondary schools. In the religious culture and moral knowledge or guidance courses at the schools of Ministry of National 
Education's, privacy activities can be held both within the scope of value and as an activity to use social media correctly. In addition to schools, digital games that can be played on technological devices such as mobile phones, tablets and computers can be produced to give privacy awareness in digital environments. In these games, points are lost when privacy violations are committed, and the goal is reached as long as there is no violation of privacy. In this way, it is foreseen that privacy awareness can be developed from a young age by supporting children to learn privacy measures while playing games.

In order to increase the functionality of the privacy value, spot sentences such as "if privacy ends, deprivation begins", "my privacy is not open to visuals", "1 protect the privacy of my family, 1 protect myself" can be written on billboards in cities. Thus, individuals and families can be attracted attention to privacy and individuals are guided to think about their privacy. At the same time, things that should be known about family privacy can be prepared as a handbook and distributed to families. In particular, the privacy limits of the word, body, area and information can be explained in detail in these handbooks. In addition, the Ministry of Family and Social Policies and the Presidency of Religious Affairs can work together to give "Privacy Education in the Family" seminars and increase awareness about privacy by explaining the importance, nature and principles of privacy. In this way, it is thought that important messages about privacy will help create a collective consciousness.

A digital application related to individual, family and spatial privacy can be made. This application can help the person to review his action by giving a warning signal such as "private area is in danger", "privacy violation", "private area is open to intervention" when individual, family or spatial privacy is exceeded. In this way, when privacy limits are violated, the application of privacy in technological products such as mobile phones and computers supports protecting the limits of privacy. With this application, information on individual and family privacy can be made on social media. In this way, children can be taught how to behave against situations such as harassment, violence and rape that may occur on social media. Finally, privacy literacy studies can be carried out to identify any situation that may violate the privacy or obscure the limits of privacy in social and virtual environments, helping to be more careful about privacy in individual and social areas. As a result, it is thought that as a result of these studies, an awareness of the value of privacy can be created, the functionality of privacy in individual and family life can be increased, and thus family unity can be protected.

\section{References}

Akalın, Ş. H. (2005). Türkçe Sözlük (10. Basım). Ankara: Türk Dil Kurumu.

Akgün, E. (2013). Ortaçağ'da Özgürlük Arayışı. Mehmet Akif Ersoy Üniversitesi Sosyal Bilimler Enstitüsü Dergisi, 5(8), 125.

https://dergipark.org.tr/tr/pub/makusobed/issue/19440/206768

Aktaş, C. (1995). Mahremiyetin Tükenişi. İstanbul: Nehir Yayınları.

Altman, I. (1976). Privacy: 'A Conceptual Analysis'. Environment and Behavior (8:1), 7-8. . https://doi.org/10.1177/001391657600800108

Arık, E. (2018). Dijital Mahremiyet Yeni Medya ve Gözetim Toplumu. Konya: Literatürk.

Arendt, Hannah. (2018). İnsanlık Durumu. (B. Sina Şener Çev.). İstanbul: İletişin Yayınları.

Aydın Avşar, S. (2019). Aşikar Mahremiyet. İstanbul: A7 Kitap Yayıncılık.

Ağaoğullar, M. A. ve Köker, L. (2004). Imparatorluktan Tanrı Devletine. Ankara: İmge Kitabevi.

Balay, R. (2004). Küreselleşme, Bilgi Toplumu ve Ĕ̈itim. Ankara Üniversitesi Eğitim Bilimleri Fakültesi Dergisi, 37 (2). 62-63. DOI: 10.1501/Egifak_0000000097

Barbarosoğlu, F. (2017). İmaj ve Takva (17. Basım). İstanbul: Profil Yayıncılık.

Barbarosoğlu, F. (2013). Şov ve Mahrem. İstanbul: Profil Yayıncılık. 
Baudrillard, J. (2003). Sessiz Yığınların Gölgesinde-Toplumsalın Sonu. (O. Adanır Çev.) Ankara: Doğu-Batı Yayınları.

Baudrillard, J. (2008). Tüketim Toplumu. (Çev. H. Deliçaylı ve F. Keskin) İstanbul: Ayrıntı Yayınları.

Bentham, J. (1995). The Panopticon Writings. London: Verso.

Bowen, G. A. (2009). Document analysis as a qualitative research method. Qualitative research journal.

Canatan, K. ve Yıldırım, D. E. (2011). Aile Sosyolojisi. İstanbul: Açılımkitap.

Critchley, S. (2013). Imansızların İmanı. (Erkal Ünal Çev.) İstanbul: Metis Yayınları.

Çağan, K. (2019). Postmodernizm ve Mahremiyetin Dönüşümü. Ankara: Pruva Yayınları .

Çoşkun, İ. (2003). Modernliğin Kaynakları: Rönesans Üzerine Bir Değerlendirme. İstanbul Üniversitesi Sosyoloji Dergisi, 3(6), 48. https://dergipark.org.tr/tr/pub/iusosyoloji/issue/528/4818.

Demir, A. (2017). Panopticon ve Synopticon Geriliminde Özgürlük Paradoksu. Uludă̆ Üniversitesi FenEdebiyat Fakültesi Felsefe Dergisi, 28, 59. https://doi.org/10.20981/kaygi.307940

Dökmen, Ü. (2000). Varolmak, Gelişmek ve Uzlaşmak. İstanbul: Sistem Yayıncılık.

Duerr, H. P. (1999). Uygarlaşma Sürecinin Miti I:Çıplaklık ve Utanç (M. Tüzel Çev.) Ankara: Dost Kitabevi Yayınlar1.

el-İsfahani, R. (2002). Müfredat (3. Basım). (thk. Safvab Adnan Davudi) Beyrut: Darü’ş-Şamiyye.

Ergil, D. (1984). Toplumsal Örgütlenmenin Yap1s1. Ankara Üniversitesi SBF Dergisi, 39 (1), 15-16. https://doi.org/10.1501/SBFder_0000001449

Ernout, A. ve Meillet, A. (2001). Dictionnaire Etymologique De La Langue Latine. Paris: Klincksieck.

Kutsal Kitap (Eski ve Yeni Antlaşma. (2014). Eski Antlaşma, Yaratılış 2,3. İstanbul: Yeni Yaşam Yayınları

Falkingham, L., \& Reeves, R. (1998). Context analysis-A technique for analysing research in a field, applied to literature on the Management of R\&D at the section level. Scientometrics, 42(2), 97-120.

Fischer-Hübner, S. (2001). IT-Security and Privacy (1. Basım). Berlin: Springer-Verlag Berlin Heidelberg.

Finn, R. L., Wright, D., ve Friedewald, M. (2013). Seven Types of Privacy. In European Data Protection: Coming of Age.

Fromm, E. (1995). Özgürlükten Kaçış. (Ş. Yeğin Çev.) İstanbul: Payel Yayınları.

Güneş Ceylan, S. (2004). Roma Hukukunun Günümüz Hukuk Düzenlerine Etkisi. Ankara Hacı Bayram Veli Üniversitesi Hukuk Fakültesi Dergisi, 8(2), 4. https://dergipark.org.tr/tr/pub/ahbvuhfd/issue/48132/608803.

Giddens, A. (1994). Mahremiyetin Dönüşümü. (İ. Şahin Çev.) İstanbul: Ayrıntı Yayınları.

Guzman, D. S. (2005). Özgürlüğe Uçuş. (Z. Erkırmış ve F. Örücü Çev.) Ankara: Yeni Yüksektepe Kültür Derneği.

Huxley, A. (2018). Cesur Yeni Dünya. (Ü. Tosun Çev.) İstanbul: İthaki Yayınları.

İbn Manzur (1997). Lisanu'l-Arabi’l-Muhit. Beyrut: Dâru'l- Fikr. C. III) , 136.

İbn Miskeveyh (2013). Tehzîbü'l-Ahlâk (A. Şener ve İ. Kayaoğlu Çev.) İstanbul: Büyüyenay Yayınları.

Kahraman, A. (2019). Fıkhi Perspektiften Sırrın İnşası. N. Şişman içinde, Mahremiyet Hayatın Sırları ve Sinırlar. İstanbul: İnsan Yayınları. 
Karagülle, A. E. (2015). Günümüzde değişen mahremiyet algısının sosyal ağlar bağlamında incelenmesi. (Yayımlanmamış yüksek lisans tezi). İstanbul Ticaret Üniversitesi, Sosyal Bilimler Enstitüsü, İstanbul.

Karasar, N. (2007). Bilimsel araştırma yöntemleri (17. baskı). Ankara: Nobel Yayıncılık.

Kır, İ. (2011). "Toplumsal Bir Kurum Olarak Ailenin İşlevleri". Elektronik Sosyal Bilimler Dergisi, 10/36 (Ocak 2011), 381. https://dergipark.org.tr/tr/pub/esosder/issue/6150/8260

Kızılçelik, S. (1996). Postmodernizm Dedikleri. İzmir: Saray Kitabevleri.

Köse, İ. (2011). Tüketim Toplumunda Bir “Sosyal Beden” Kurgusu Olarak Kadın”. Selçuk İletişim, 6/4 (Ekim 2011), 78. http://hdl.handle.net/123456789/12298

Kutsal Kitap: Tevrat, Zebur İncil (2008). İstanbul: Kitabı Mukaddes Şirketi -Yeni Yaşam Yayınları.

Lokke, E. (2020). Mahremiyet: Dijital Toplumda Özel Hayat (2. Basım). (D. Başak İbn Miskeveyh (2013). Tehzîbü'l-Ahlâk) Koç Üniversitesi Yayınları.

Madge, J. (1965). The tools of science an analytical description of social scince techniques. Garden City: Anchor Books Doubleday and Comp.

Martı, H., Martı, H. Ö., Yıldız, F. ve Çınar, M. (2020). Íslam'da Mahremiyet (2.Basım). Ankara: Türkiye Diyanet Vakfi Yayınları.

Mill, J. S. (2001). On Liberty. Kitchener: Batoche Books.

Müftüoğlu, A. (2019). Vakti Kuşanmak (9. Basım). İstanbul: Mahya Yayıncılık.

Newell, B. C., Metoyer, C. A. ve Moore, A. D. (2015). Privacy in family.B. Roessler and D. Mokrosinska (Ed.), The Social Dimensions of Privacy. London: Cambridge University Press.

Neiman, S. (2016). Ahlâki Açıklık. (N.Tokdoğan Çev.) İstanbul: İletişim Yayınları.

Neiman, S. (2017). Niçin Büyüyelim? Çocuksu Bir Çă̆ Için Altüst Edici Düşünceler. (N. Tokdoğan Çev.) İstanbul: İletişim Yayınları.

Niedzviecki, H. (2011). Ben Özelim! Bireysellik Nasıl Yeni Konformizm Haline Geldi. (S. Erduman Çev.) İstanbul: Ayrıntı Yayınları.

Niedzviecki, H. (2010). Dikizleme Günlüğü (1. Basım). (G. Gündüç Çev.) İstanbul: Ayrıntı Yayınları.

Okuyan, M. (2019). Çok Anlamlılık Bağlamında Kur'an Sözlüğü (7. Basım). İstanbul: Düşün Yayıncılık.

Orwell, G. (2019). 1984. (C. Sürer Çev.) İstanbul: Can Sanat yayınları.

Özdel, G. (2012). Foucault Bağlamında İktidarın Görünmezliği ve "Panoptikon" ile "İktidarın Gözü" Göstergeleri. The Turkish Online Journal of Design, Art and Communication, 2(1), 23. DOI:10.7456/10201100/003

Pekdemir, Ş. (2016). Mahremiyet Algısı Hak Olgusu. Din, Gelenek ve Ahlak Bağlamında Mahremiyet Algıları Sempozyumu (Cilt I). Samsun: ORIV Yayınları.

Reber, A. S. (1985). Dictionary of Pyschology. London: Penguin Books.

Sakl1, A. R. (2013). Fordizm'den Esnek Üretim Rejimine Geçişin Kamu Yönetimi Üzerindeki Etkileri”. Elektronik Sosyal Bilimler Dergisi, 12/44, 109. https://dergipark.org.tr/tr/pub/esosder/issue/6158/82766

Sayar, K. ve Yalaz, B. (2019). Ağ Sanal Dünyada Gerçek kalmak. İstanbul: Kapı Yayınları. 
Seipp, D. J. (1983). English judicial recognition of a right to privacy. Oxford Journal of Legal Studies, 3(3), 3501. https://doi.org/10.1093/ojls/3.3.325

Sennett, R. (2002). Ten ve Taş: Batı Uygarlı̆̆ında Beden ve Şehir. (T. Birkan Çev.). İstanbul: Metis Yayınları.

Solove, D. J. (2011). Nothing to Hide. New Haven: Yale University Press.

Subaşı, N. (2007). Sınırları Yoklamak. İstanbul: Ötüken Neşriyat.

Türker, Ö. (2019). İslam Düşünce Geleneklerinde Mahremiyet Kavramı. Nazife Şişman (Ed.). Mahremiyet Hayatın Sirları ve Sinırları. içinde İstanbul: İnsan Yayınları.

Toffler, A. (1981). Üçüncü Dalga. (A. Seden Çev.) İstanbul: İstanbul Kitaplar Yayınevi.

Toffler, A. (1974). Şok. (S. Turgut Çev.) İstanbul: İstanbul Kitaplar Yayınevi.

Touraine, A. (2010). Modernliğin Eleştirisi (7. Basım). (H. Tufan Çev.). İstanbul: Yapı Kredi Yayınları.

Trepte, S. ve Masur, Philip K. (2017). Need for privacy. T. K. Virgil Zeigler-Hill (Ed.). Encyclopedia of personality and individual differences. London: Springer.

Tunç Yaşar, F. (2019). Osmanlı Dünyasında Mahremiyet: İfşa ile İhlal Arasında. N. Şişman (Ed.) Mahremiyet: Hayatın Sirları ve Sinırlart. İstanbul: İnsan Yayınları.

Turow, J. (2011). The Daily You: How the New Advertising Industry is Defining Your Identity and Your Worth. New Haven, CT: Yale University Press.

Vincent, D. (2017). Mahremiyet Kısa Bir Tarih. (D. C. Başaraner Çev.) İstanbul: Epos Yayınları.

Warren, S. D. ve Brandeis, L. D. (1890). The Right to Privacy. Harvard Law Review, 4 (5).

Westin, A. F. (1968). Privacy and Freedom. New York, United States: Atheneum.

Yavuz, H. (2012). Budalalı̆̆ın Keşfi (1. Basım). İstanbul: Timaş Yayınları.

Yeşil Çelik, B. (2020). Mahremiyetin Dönüşümü: Sosyal Medyada Özel Hayatın Sunumu. (Yayımlanmamış yüksek lisans tezi), Ankara Üniversitesi, Sosyal Bilimler Enstitüsü, Ankara.

Yıldırım, A. (1999). Nitel araştırma yöntemlerinin temel özellikleri ve eğitim araştırmalarındaki yeri ve önemi. Eğitim ve Bilim, 23(112).

Yıldırım, A., \& Şimşek, H. (2008). Sosyal Bilimlerde Nitel Araştırma Yöntemleri (6. Baskı).

Ankara: Seçkin Yayıncılık.

Zeldin, T. (1998). İnsanlığın Mahrem Tarihi. (E. Özsayar Çev.). İstanbul: Ayrıntı Yayınları. 